\title{
Effect of Silicate and Phosphate Solubilizing Rhizobacterium Enterobacter ludwigii GAK2 on Oryza sativa L. under Cadmium Stress
}

\author{
Arjun Adhikari, Ko-Eun Lee, Muhammad Aaqil Khan, Sang-Mo Kang, Bishnu Adhikari, Muhammad Imran, \\ Rahmatullah Jan, Kyung-Min Kim and In-Jung Lee*
}

School of Applied Biosciences, Kyungpook National University, Daegu 41566, Republic of Korea

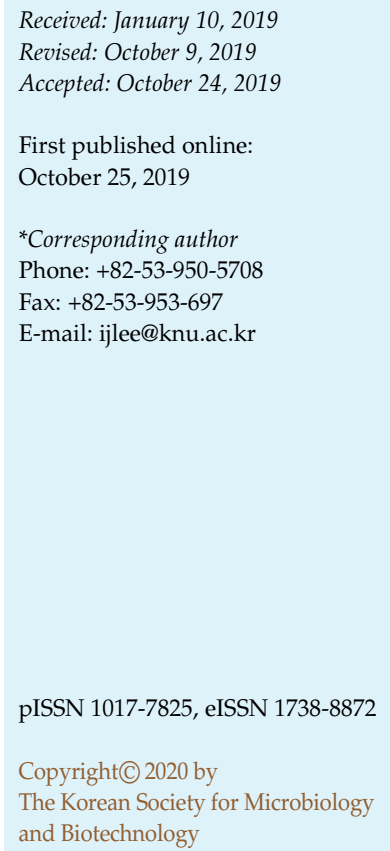

Silicon and phosphorus are elements that are beneficial for plant growth. Despite the abundant availability of silicate and phosphate in the Earth's crust, crop nutritional requirements for silicon and phosphorus are normally met through the application of fertilizer. However, fertilizers are one of the major causes of heavy metal pollution. In our study, we aimed to assess silicate and phosphate solubilization by the bacteria Enterobacter ludwigii GAK2, in the presence and absence of phosphate $\left[\mathrm{Ca}_{3}\left(\mathrm{PO}_{4}\right)_{2}\right]$ or silicate $\left(\mathrm{Mg}_{2} \mathrm{O}_{8} \mathrm{Si}_{3}\right)$, to counteract cadmium stress in rice (Oryza sativa L). Our results showed that the GAK2-treated rice plants, grown in soil amended with phosphate $\left[\mathrm{Ca}_{3}\left(\mathrm{PO}_{4}\right)_{2}\right]$ or silicate $\left(\mathrm{Mg}_{2} \mathrm{O}_{8} \mathrm{Si}_{3}\right)$, had significantly reduced cadmium content, and enhanced plant growth promoting characteristics including fresh shoot and root weight, plant height, and chlorophyll content. These plants showed significant downregulation of the cadmium transporter gene, OsHMA2, and upregulation of the silicon carrier gene, OsLsi1. Moreover, jasmonic acid levels were significantly reduced in the GAK2-inoculated plants, and this was further supported by the downregulation of the jasmonic acid related gene, OsJAZ1. These results indicate that Enterobacter ludwigii GAK2 can be used as a silicon and phosphorus bio-fertilizer, which solubilizes insoluble silicate and phosphate, and mitigates heavy metal toxicity in crops.

Keywords: Cadmium, Enterobacter ludwigii GAK2, phosphorus, rice, silicon

\section{Introduction}

Heavy metals have been widely disseminated for sustainable agriculture and human well-being [1]. They have been excessively exposed in the environment through anthropogenic activities. Although, many of these metals under threshold concentrations serve as vital nutrients for plant growth, when they exceed their threshold limits, they impose toxicity in nature [1]. Heavy metals such as cadmium (Cd) are highly toxic to plants, even at low concentrations [2]. Its threshold value in soil is $1 \mathrm{mg} / \mathrm{kg}$, and it presents ecological risks if levels in soil exceed $10 \mathrm{mg} / \mathrm{kg}[2,3]$. Furthermore, $\mathrm{Cd}$ is ranked as the $7^{\text {th }}$ most highly toxic element [4].

Phosphate fertilizers are considered as the major causative factor for $\mathrm{Cd}$ contamination of agricultural land [5-7]. When crops uptake $\mathrm{Cd}$, this can lead to high levels of
$\mathrm{Cd}$ in the human food chain [7]. In Japan, itai-itai disease was caused by $\mathrm{Cd}$ contamination, and resulted in the deaths of several hundred people in the 1950s [8]. Therefore, the contamination of the food chain with $\mathrm{Cd}$ is considered a major threat to human health [5].

In recent years, heavy metal-resistant bacteria and silicon (Si) have become known as biologically safe tools to mitigate heavy metal toxicity in plants $[10,11]$. The application of $\mathrm{Si}$ has significant beneficial effects on several plant species. It has been reported that Si reduces the detrimental effects of various heavy metals like manganese [12], aluminium [13], zinc [14], and copper [15]. There are several reports about the key role of $\mathrm{Si}$ in alleviating $\mathrm{Cd}$ toxicity in plants through a reduction in uptake of cadmium [16-18]. Si plays a key role in alleviating $\mathrm{Cd}$ toxicity by also decreasing $\mathrm{Cd}$ accumulation in the plant shoot, and by stimulating the plant's defense system [19]. The Earth's crust is rich in 
silicate and phosphate. However, plants can only absorb Si as monosilicic acid $\left(\mathrm{H}_{4} \mathrm{SiO}_{4}\right)$ [20] and phosphorus $(\mathrm{P})$ as $\mathrm{H}_{2} \mathrm{PO}_{4}$ and $\mathrm{HPO}_{4}^{2-}[21]$. On the other hand, the massive use of $\mathrm{P}$ fertilizer causes global economic and environmental problems such as increased $\mathrm{P}$ prices, higher agricultural production costs and elevated net accumulation of $\mathrm{P}$ in soil and heavy metal toxicity [22, 23]. Moreover, significant loss of $\mathrm{P}$ through leaching and runoff from agricultural land generates huge discharges into water bodies that accelerates eutrophication [24]. An overview of these scenarios in terms of $\mathrm{Si}$ and $\mathrm{P}$ fertilizer application represents lower utilization of resources, extravagant investment and threat to the environment and food chain. Therefore, there is undoubtely an urgent need for fertilizer that can eliminate the metal toxicities from crops and enhance productivity in an eco-friendly manner along with the amelioration of the soil toxicity problem.

Plant growth promoting rhizobacteria (PGPR) have recently been considered as eco-friendly bioferilizer that tends to immobilize heavy metals and inhibit its translocation in plants [25]. Moreover, PGPR upregulate the plant defense system through stimulation of antioxidant activity, modulation of phytohormones and regulation of metal transporter genes [1, 26]. PGPR are reported to confer resistance to plants under heavy metal stress through production of plant hormones such as indole-3-acetic acid (IAA) and gibberellins. In addition, PGPR produce organic acid, 1-aminocyclopropane-1-carboxylate (ACC)-deaminase, and solubilize phosphate that enhance defense mechanisms and minimize heavy metal translocation within the plant tissues [1, 27]. Among PGPR, phosphate solubilizing bacteria have been widely reported to confer tolerance in plants under biotic and abiotic stress [28]. However, studies on silicate solubilizing bacteria are largely ignored. Since researchers of the past few decades have highly prioritized the importance of silicon especially in a high siliconaccumulator crops like rice, their studies have focused on sustaining the silicon and phosphorus demand in plants through the application of silicate and phosphate solubilizing PGPR in a rice plants.

Rice is the most stable cereal crop plant in the world, feeding approximately half of the global population [29]. Exposure of $\mathrm{Cd}$ in environment had led to toxic rice production, which upon intake may impose a severe threat to humankind. [30]. In addition to toxic production, $\mathrm{Cd}$ also alters the normal physiology of plants. In general, when $\mathrm{Cd}$ is accumulated by plants it causes phytotoxicity, lowers plant nutrient uptake, and inhibits the photosynthetic process [31, 32]. Several studies have showed that metal resistant bacteria that are involved in phytohormone production and phosphate solubilization stimulate plant growth and mitigate heavy metal toxicity $[33,34]$. In the current study, we have selected the strain that could resist heavy metal and has high ability for silicate and phosphate solubilization, as well as IAA and gibberellin (GA) production [35].

Here, we demonstrate how silicate and phosphate solubilization in soil through microorganisms could minimize the $\mathrm{Cd}$ uptake and improve the physiology of rice plants under cadmium stress. Our work shows that the application of silicate and phosphate solubilizing bacteria could solubilize insoluble silicate and phosphate in soil, and thereby reduce the requirement for phosphate fertilizer application, mitigate $\mathrm{Cd}$ toxicity, and enhance the growth and production quality of the plants.

\section{Materials and Methods}

\section{Silicate and Phosphate Solubility Performance Test}

The bacterial strain Enterobacter ludwigii GAK2, which was registered with accession number KP 676113 in the NCBI database, (Lee 2015) https:/ /www.ncbi.nlm.nih.gov/nuccore/830699107, was selected for conducting the experiment. The bacterial bioassay of resistance to heavy metals was perfomed in glucose media (glucose $10 \mathrm{~g} / \mathrm{l}$, with $0.25 \% \mathrm{Mg}_{2} \mathrm{O}_{8} \mathrm{Si}_{3}$ ) and National Botanical Research Institute's Phosphate (NBRIP) growth media [glucose $10 \mathrm{~g} / \mathrm{l}, \mathrm{MgCl}_{2} \cdot 6 \mathrm{H}_{2} \mathrm{O} 5 \mathrm{~g} / \mathrm{l}, \mathrm{MgSO}_{4} \cdot 7 \mathrm{H}_{2} \mathrm{O} 0.25 \mathrm{~g} / \mathrm{l}, \mathrm{KCl} 0.2 \mathrm{~g} / \mathrm{l}$, $\left(\mathrm{NH}_{4}\right)_{2} \mathrm{SO}_{4} 0.1 \mathrm{~g} / 1$ with $0.25 \% \mathrm{Ca}_{3}\left(\mathrm{PO}_{4}\right)_{2}$ ] with or without $\mathrm{Cd}$ with random concentrations from $100 \mu \mathrm{M}$ to $1,500 \mu \mathrm{M}$. Paper discs were placed on media plates and $20 \mu \mathrm{l}$ of each bacterial culture (optical density $>1$, at $660 \mathrm{~nm}$ measured by UV spectrophotometer, PG instrument T60U, UK) was added and incubated at $30^{\circ} \mathrm{C}$. A visual assessment of solubilization ability through observing a clear zone in the media plates was performed and used for further testing.

\section{Experimental Design}

The effect of GAK2 was investigated with insoluble silicate (IS) and insoluble phosphate (IP) along with cadmium. The experiment involved the following treatments: Control (Cd), IS+Cd $\left(\mathrm{Mg}_{2} \mathrm{O}_{8} \mathrm{Si}_{3}\right.$ and Cadmium), GAK2+Cd (Bacteria and Cadmium), IS+GAK2+Cd $\left(\mathrm{Mg}_{2} \mathrm{O}_{8} \mathrm{Si}_{3}+\right.$ Bacteria $\left.+\mathrm{Cd}\right), \mathrm{IP}+\mathrm{Cd}\left(\mathrm{Ca}_{3}\left(\mathrm{PO}_{4}\right)_{2}\right.$ and Cadmium $)$, $\mathrm{IP}+\mathrm{GAK} 2+\mathrm{Cd}\left(\mathrm{Ca}_{3}\left(\mathrm{PO}_{4}\right)_{2}+\right.$ Bacteria+Cadmium $)$.

\section{Determination of Soil pH for Plant Experiment}

The selection of appropriate doses of $\mathrm{Mg}_{2} \mathrm{O}_{8} \mathrm{Si}_{3}$ or $\mathrm{Ca}_{3}\left(\mathrm{PO}_{4}\right)_{2}$ was based on the previous study done by Lee et al. [29]. Here, autoclaved $\left(121^{\circ} \mathrm{C}, 15 \mathrm{~min}, 3\right.$ times) nursery paddy soil ( $200 \mathrm{~g}$ per pot) was placed in sealed pots with a size of $10 \times 10 \mathrm{~cm} . \mathrm{Mg}_{2} \mathrm{O}_{8} \mathrm{Si}_{3}$ or $\mathrm{Ca}_{3}\left(\mathrm{PO}_{4}\right)_{2}$ in quantities of $0.0 \mathrm{~g}, 0.2 \mathrm{~g}, 0.4 \mathrm{~g}, 0.6 \mathrm{~g}, 0.8 \mathrm{~g}, 1.0 \mathrm{~g}$, 
$2.0 \mathrm{~g}$, were added to the $10 \times 10 \mathrm{~cm}$ pots and mixed thoroughly. Distilled water $(100 \mathrm{ml})$ was poured on each pot and the $\mathrm{pH}$ was measured after $24 \mathrm{~h}$ according to the procedure described by Kalra [36]

\section{Plant Material and Pot Experiment}

The Korean rice cultivar Hwayeongbyeo was selected for the pot experiment to investigate the effect of E. ludwigii GAK2 under cadmium stress. The rice variety was developed by the Rural Development Administration, South Korea. Yeongnam Agricultural Experiment Station, South Korea, reported the variety as a first generation of cultivar Chukei 830 and YR 4811 Acp 8. The autoclaved soil $\left(121^{\circ} \mathrm{C}, 15 \mathrm{~min}, 3\right.$ times) and similar pots as mentioned in section 2.3 were filled with $200 \mathrm{~g}$ autoclaved $\left(121^{\circ} \mathrm{C}, 15 \mathrm{~min}, 3\right.$ times) nursery paddy soil for the current experiment. To each pot, $0.4 \mathrm{~g}$ of either $\mathrm{Mg}_{3} \mathrm{Si}_{2} \mathrm{O}_{8}$ or $\mathrm{Ca}_{3}\left(\mathrm{PO}_{4}\right)_{2}$ was added and two-week-old rice seedlings were transplanted.

Bacterial culture (grown on LB of O.D > 1) was kept in a $250 \mathrm{ml}$ bottle, and centrifuged at $6,000 \times g$ for $10 \mathrm{~min}$ at $4^{\circ} \mathrm{C}$. The pellets obtained were diluted with sterilized with distilled water to form $10^{8}$ colony-forming units (CFU) per milliliter. Five days after seedling transplantation, $50 \mathrm{ml}$ of freshly diluted bacterial culture was inoculated to each pot; this was repeated after a further 5 days. Five days after the second inoculation, $80 \mathrm{ml}$ of $1 \mathrm{mM}$ $\mathrm{CdSO}_{4} \cdot 8 \mathrm{H}_{2} \mathrm{O}$ was added to each pot for 7 consecutive days. After 5 days the plants were harvested, and their morphological parameters (root length, shoot length, fresh root and shoot weight, plant height) and chlorophyll content (SPAD-502, Konica Minolta, Japan) were measured. Fresh samples were separated for RNA extraction and others were lyophilized, ground, and further biochemical analysis was performed. The entire experiment was conducted in a growth chamber (KGC-175 VH, KOENCON) and conditions were programmed for a 12 -h light $\left(08: 00 \sim 20: 00 ; 30^{\circ} \mathrm{C}\right.$; relative humidity $68 \%), 12$-h dark $\left(20: 00 \sim 08: 00,24^{\circ} \mathrm{C}\right.$; relative humidity $68 \%$ ) cycle.

\section{Quantification of Cadmium Content in Rice Plants}

The method described by Kang et al. [37] was followed to quantify the $\mathrm{Cd}$ content. Lyophilized and powdered rice samples $(0.5 \mathrm{~g})$ were soaked briefly with $0.5 \mathrm{M} \mathrm{HCl}$, and rinsed through double distilled water before oven drying. A mixture of nitric acid, sulfuric acid and perchloric acid at (10:1:4 v/v/v) was subjected through the sample. The digested sample obtained was then analyzed with an Inductively Coupled Plasma machine (Optima 7900DV, Perkin-Elmer, USA).

\section{RNA Isolation and qPCR Analysis of Selected Genes}

The RNA was extracted by following the protocol described by Chan et al. [38] . The expression level of Si-carrying gene (OsLsi1), $\mathrm{Cd}$-carrying gene (OsHMA2), and jasmonic acid related gene (OsJAZ1) were analyzed by qPCR [39]. In brief, cDNA was synthesized using a qPCRBIO cDNA Synthesis Kit following the manufacturer's instructions. qPCRBIO SYBR Green Kit from
PCRBIOSYSTEM was used following the manufacturer's instructions to conduct the reaction. q-PCR was conducted using Illumina Eco Real-Time PCR System (Singapore), to relatively quantify the expression level of selected genes. The primers of OsLsi1 (Accession No. N17-020055), OsHMA2 (Accession No. XM-015788173) and OsJAZ1 (Accession No. XM-015757562) were used as a reference (Table S2). To standardize the level of expression, OsActin was used as housekeeping gene. The total volume of the reaction was $20 \mu \mathrm{l}$ containing $7 \mu \mathrm{lddH_{2 }} \mathrm{O}, 1 \mu \mathrm{l}$ primer, $10 \mu \mathrm{l}$ SYBR Green and $1 \mu \mathrm{l}$ cDNA.

\section{Jasmonic Acid (JA) Quantification}

Standard protocol of McCloud and Baldwin [40] as described in Shahzad et al. [41] was followed to quantify the JA content in the plants. Briefly, $0.1 \mathrm{~g}$ of freeze-dried sample was extracted with acetone, followed by the addition of dd. $\mathrm{H}_{2} \mathrm{O}$ and JA standard. The acetone was evaporated, and $0.1 \mathrm{M}$ phosphate buffer was added, and the $\mathrm{pH}$ was adjusted to between 2 and 3. Chlorophyll was removed with diethylaminoethyl (DEAE) cellulose and partitioned with chloroform. The solution was then run through an $\mathrm{NH}_{2}$ cartridge and finally quantified with a gas chromatography select ion monitoring (GC-SIM) (6890N network GC system and the 5973 network mass selective detector; Agilent Technologies, USA).

\section{Statistical Analysis}

The present study was conducted in a completely randomized design in which each treatment had 8 replicates. Statistical analysis was performed with the program $\mathrm{R}$ and the data are presented as the means \pm standard deviation (SD). Significant differences among treatments were determined using the least significant difference (LSD) method at $p \leq 0.05$.

\section{Results}

\section{Bioassay of Enterobacter ludwigii GAK2}

Our research revealed that E. ludwigii GAK2 could solubilize the insoluble silicate and phosphate in the presence of cadmium ( $\left.1 \mathrm{mM} \mathrm{CdSO}_{4} \cdot 8 \mathrm{H}_{2} \mathrm{O}\right)$. Based on these results, $1 \mathrm{mM} \mathrm{CdSO} \mathrm{m}_{4} \cdot 8 \mathrm{H}_{2} \mathrm{O}$ was applied during the plant experiment. The clear, circular zones formed around the bacterial colonies indicated silicate solubilization in the glucose media with silicate, and phosphate solubilization in the NBRIP media with phosphate, respectively (Fig. 1).

\section{Determination of $\mathrm{pH}$ Value at Different Concentrations of $\mathrm{Ca}_{3}\left(\mathrm{PO}_{4}\right)_{2}$ and $\left(\mathrm{Mg}_{2} \mathrm{O}_{8} \mathrm{Si}_{3}\right)$}

The $\mathrm{pH}$ value of soil increased as the amount of added $\mathrm{Mg}_{2} \mathrm{O}_{8} \mathrm{Si}_{3}$ increased. The application of $0.4 \mathrm{~g}$ of $\mathrm{Mg}_{2} \mathrm{O}_{8} \mathrm{Si}_{3}$ resulted in a soil $\mathrm{pH}$ between 5.5-6. However, the application of $\mathrm{Ca}_{3}\left(\mathrm{PO}_{4}\right)_{2}$ did not influence the $\mathrm{pH}$ value of soil (Fig. 2). 


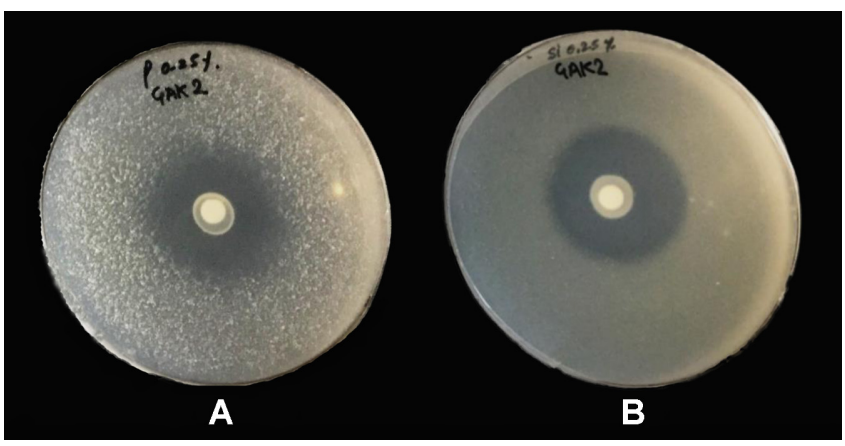

Fig. 1. Screening of silicate and phosphate solubility performance test of Enterobacter ludwigii GAK2 under Cd stress 1,000 $\mu \mathrm{M}$.

(A) Silicate solubilization test on glucose agar media plate with $0.25 \%$ magnesium trisilicate. (B) Phosphate solubilization test on NBRIP agar media plate with $0.25 \%$ calcium phosphate (clear zone on the media plate represents the solubilization ability of Enterobacter ludwigii GAK2).

\section{Analysis of Cadmium Content in Rice Shoots}

This study showed that Cd content was significantly higher in control plants, but upon inoculation of GAK2, the $\mathrm{Cd}$ content was significantly reduced by $34 \%$. Approximately $94 \% \mathrm{Cd}$ uptake was decreased in plant shoots grown on the IS amended soil with bacterial inoculation (IS + GAK2), as compared to control. Likewise, Cd content was significantly reduced by $51 \%$ in plant shoots grown on the IP amended soil with bacterial inoculation (IP + GAK2) (Fig. 3). Compared to the control, the sole application of IS and IP reduced the cadmium content by $86 \%$ and $18 \%$ respectively.

\section{Silicon and Cadmium Carrying Gene Expression Analysis}

The expression of the silicon transporter gene, OsLsi1 was found to be significantly higher in IS + GAK2 and in

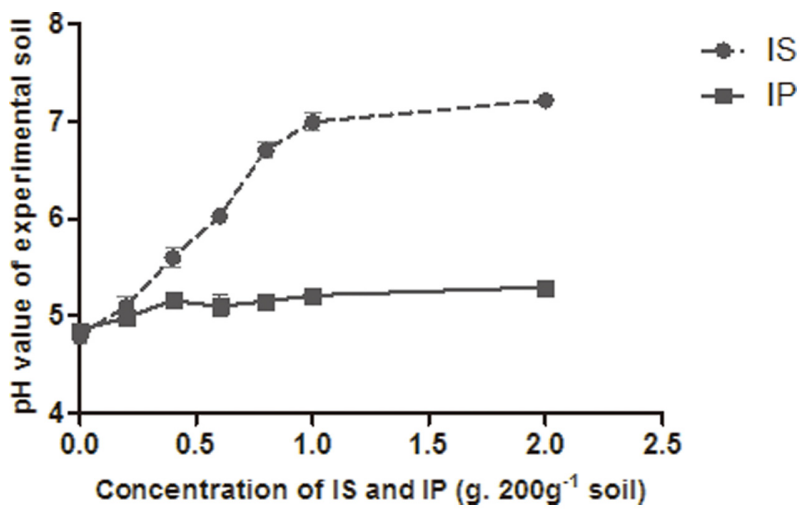

Fig. 2. $\mathrm{pH}$ value of soil under different concentrations of insoluble phosphate (IP) and insoluble silicate (IS).

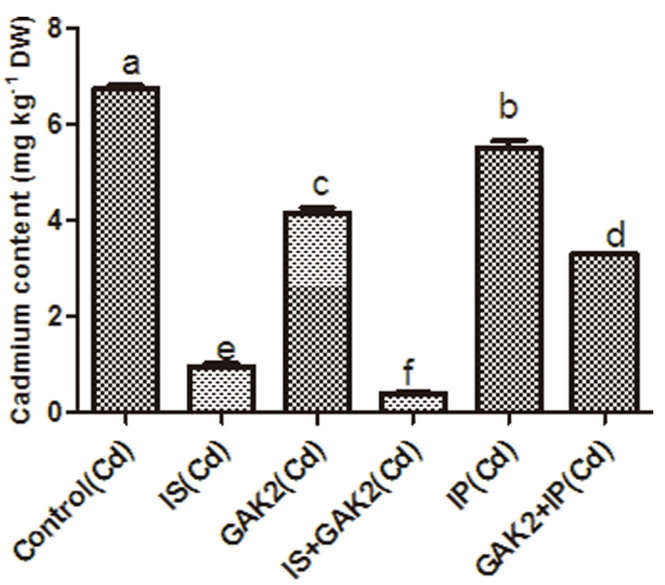

Fig. 3. Quantification of cadmium content of rice shoot.

IP+GAK2 compared to that in the control. The $\mathrm{Cd}$ transporter gene, OsHMA2 showed significantly lower expression in IS+GAK2 and IP + GAK2 when compared to control. Moreover, the sole application of IS significantly
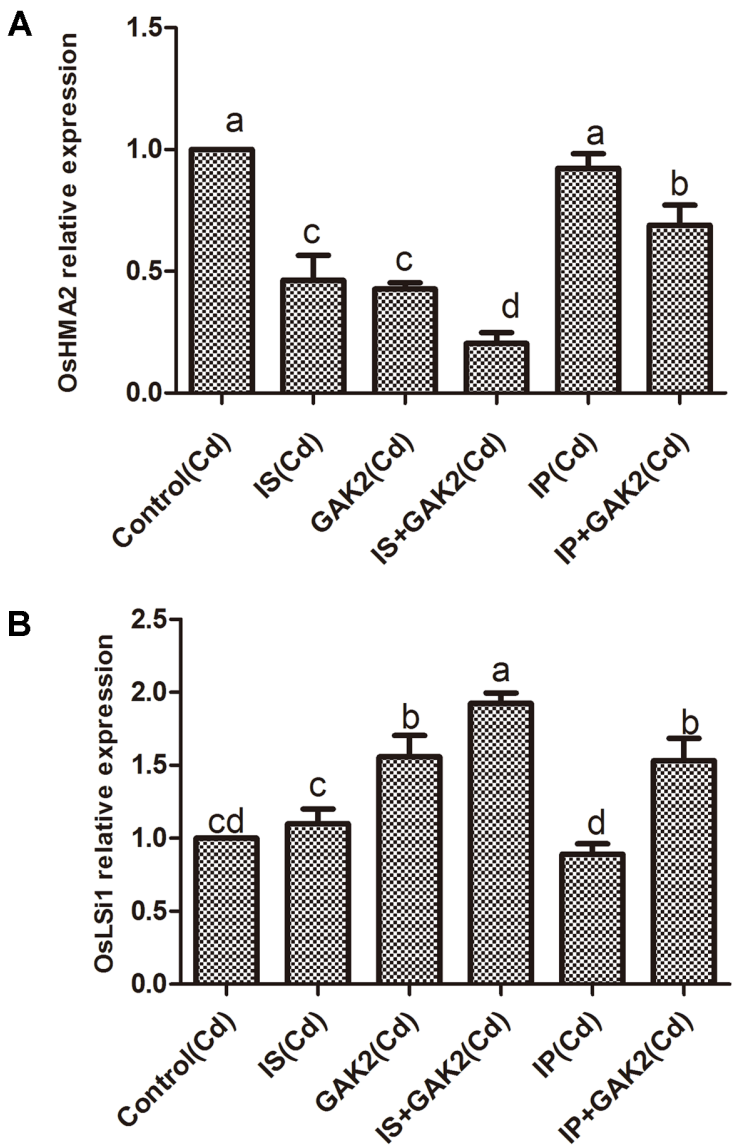

Fig. 4. Expression of cadmium transporter gene (A) OsHMA2 and (B) silicon-carrying OsLsil gene in rice plants (Oryza sativa). 
Table 1. Effect of Enterobacter ludwigii GAK2 on plant growth promoting attributes in rice plants (Oryza sativa).

\begin{tabular}{lcccc}
\hline \multicolumn{1}{c}{ Treatment } & F. Sh. Wt. (g/plant) & PH (cm/plant) & Chl. (SPAD) & F.Rt.Wt. (g/plant) \\
\hline Control(Cd) & $2.83 \pm 0.31^{\mathrm{c}}$ & $52 \pm 2^{\mathrm{c}}$ & $34 \pm 2.65^{\mathrm{c}}$ & $0.4 \pm 0.1^{\mathrm{d}}$ \\
IS(Cd) & $3.85 \pm 0.28^{\mathrm{b}}$ & $57.33 \pm 2^{\mathrm{a}}$ & $37.7 \pm 4.3^{\mathrm{bc}}$ & $0.67 \pm 0.06^{\mathrm{cd}}$ \\
GAK2(Cd) & $3.80 \pm 0.36^{\mathrm{b}}$ & $56.33 \pm 2.08^{\mathrm{ab}}$ & $41.13 \pm 1.5^{\mathrm{ab}}$ & $0.8 \pm 0.09^{\mathrm{bc}}$ \\
IS+GAK2 (Cd) & $4.53 \pm 0.31^{\mathrm{a}}$ & $59.33 \pm 1.53^{\mathrm{a}}$ & $41.93 \pm 3.44^{\mathrm{ab}}$ & $1.19 \pm 0.25^{\mathrm{a}}$ \\
IP(Cd) & $4.2 \pm 0.45^{\mathrm{ab}}$ & $53 \pm 3^{\mathrm{bc}}$ & $37.9 \pm 1.13^{\mathrm{bc}}$ & $0.77 \pm 0.10^{\mathrm{bc}}$ \\
IP+GAK2(Cd) & $4.73 \pm 0.35^{\mathrm{a}}$ & $56 \pm 2^{\mathrm{ab}}$ & $45.53 \pm 4.01^{\mathrm{a}}$ & $0.98 \pm 0.11^{\mathrm{ab}}$ \\
\hline
\end{tabular}

F.Sh.Wt: Fresh Shoot Weight, PH: Plant Height, Chl: Chlorophyll Content, F.Rt.Wt: Fresh Root Weight, GAK2: Bacteria, IS: Insoluble silicate (Magnesium trisilicate), IP: Insoluble Phosphate (Calcium phosphate), Cd: Cadmium, SPAD: Soil Plant Analysis Development Chlorophyll Meter. The mean values followed by different superscripts in the same column represent significant differences $(p \leq 0.05)$. Each value represents mean $\pm \operatorname{SD}(n=6)$.

reduced the expression of OsHMA2; however, no significant difference was observed in OsLsi1 expression (Fig. 4).

\section{Plant Growth Promoting Attributes}

The plant growth promoting attributes of fresh root weight, fresh shoot weight, plant height, and chlorophyll content were all significantly reduced in the $\mathrm{Cd}$ stressed plants. However, all these attributes were significantly increased when treated with GAK2. Under Cd stress, IS+GAK2 significantly improved plant growth (fresh root weight $197 \%$, fresh shoot weight $61 \%$, height $14 \%$, and chlorophyll content $23 \%$ ) compared to those of the control. Similar trends were observed in GAK2+IP application which significantly increased (fresh root weight 147\%, fresh shoot weight $67 \%$, plant height $7.6 \%$, and chlorophyll content $34 \%$ ) when compared with control. The sole application of GAK2, IS and IP also promoted the plant growth promoting characteristics under Cd stress. Overall, combined application of IS and GAK2 has significant effect on plant growth among all the treatments (Table 1 ).

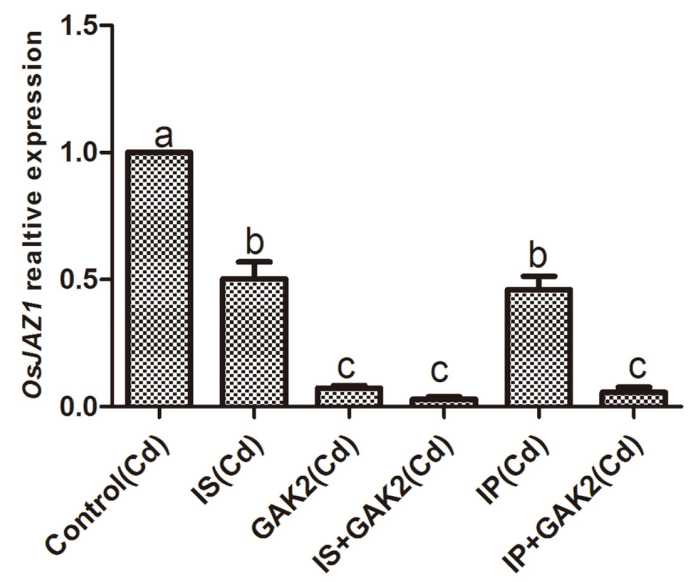

Fig. 5. Jasmonic acid related OsJAZ1 gene expression of rice shoot.

\section{Jasmonic Acid (JA) Analysis}

Under Cd stress, the JA content of the Cd stressed plants was significantly higher when compared to control. However, inoculation of GAK2 solely and along with IS and IP significantly reduced the JA content when compared to control. No significant difference was observed on sole application of IS. Sole application of GAK2 reduced JA content by $26 \%$. Similarly, JA content was significantly reduced by $39 \%$ in IP+GAK2 and by $42 \%$ in IS+GAK2. Furthermore, the levels of JA were correlated with the JA related OsJAZ1 expression. Expression of OsJAZ1 was significantly higher in the $\mathrm{Cd}$ stressed plants. However, the expression of OsJAZ1 was significantly reduced in IS+GAK2 and IP+ GAK2 when compared to control (Figs. 5 and 6).

\section{Discussion}

$\mathrm{Si}$ is considered an essential nutrient for plants, especially in rice, which is also known as a Si hyperaccumulator [42]. It has been reported that only $10-30 \%$ of phosphate

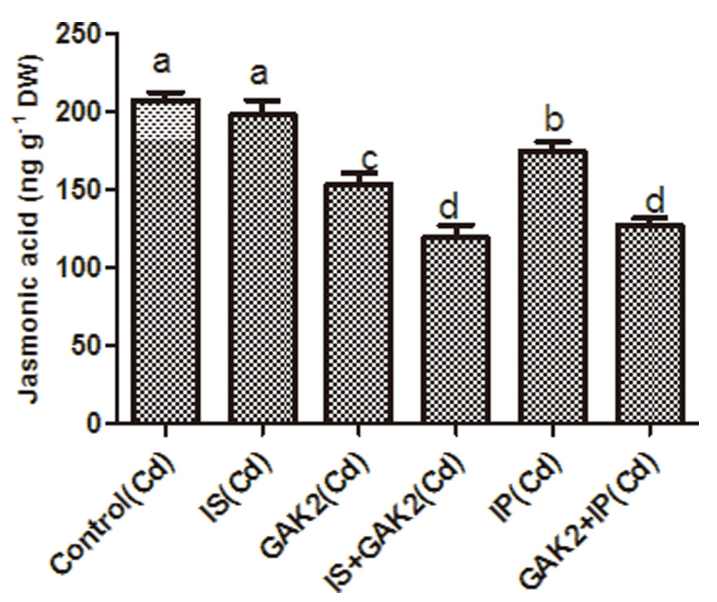

Fig. 6. Quantification of jasmonic acid of rice shoot. 
fertilizer is utilized by plants, whereas the remaining fertilizer is rapidly converted into a form which is unavailable for plant uptake [43,44]. We attempted to meet the $\mathrm{Si}$ and $\mathrm{P}$ demands of rice through the solubilization of insoluble silicate and phosphate. Through screening, it was found that the strain E. ludwigii GAK2 could efficiently solubilize silicate and phosphate, in glucose and NBRIP media. A similar method of solubilization process was reported by Naureen et al. [45], who found that acid producing bacteria formed a clear zone through silicate solubilization. Moreover, the strain GAK2 possesses an innate ability to survive in the presence of heavy metals including $\mathrm{Cd}, \mathrm{Ni}, \mathrm{Zn}$, and $\mathrm{Cu}$ (Figs. S1 and S2). We also found that GAK2's solubilization ability decreases as the heavy metal concentration increases. Nevertheless, GAK2 could efficiently solubilize silicate and phosphate, up to concentrations of $1,000 \mu \mathrm{M} \mathrm{CdSO} \cdot 8 \mathrm{H}_{2} \mathrm{O}$, on glucose and NBRIP media, respectively. Therefore, GAK2 was further investigated by inoculation in 'Hwayeongbyeo' rice plants to test mitigation effects against $\mathrm{Cd}$ stress on IS and IP mediated soil.

The issue of heavy metal toxicity is of global concern. The presence of $\mathrm{Cd}$ ions is responsible for interfering with the uptake, transport, and distribution of several mineral nutrition elements in plants $[46,47]$. In the current study, the suppression of $\mathrm{Cd}$ uptake in rice shoots because of the application of GAK2, with either IS or IP, indicates that GAK2 plays a key role in mitigating phytotoxicity in plants. There are several reports that have mentioned the beneficial effect of $\mathrm{Si}$ on the reduction of heavy metal concentration in plants. Since GAK2 has the ability to solubilize the insoluble silicate to soluble form, the possible Si-plant interaction might have lowered the $\mathrm{Cd}$ content in the plant. The OsLsil gene is reportedly used for $\mathrm{Si}$ transmission, and OsHMA2 for Cd transport in rice [39]. In this study, the higher expression of OsLsil, and lower expression of OsHMA2, on inoculation with GAK2, is further evidence of silicate and phosphate dissolution. Moreover, organic compounds are reported to play a key role in metal solubilization [48]. It has been already reported that Enterobacter ludwigii GAK2 has the ability to produce organic acids, like acetic acid, citric acid, and lactic acid [49]. These acids might have played a role in metal regulation in plants.

Metal-resistant microorganisms have various strategies to colonize heavy metal-polluted soils according to Meharg and Cairney [50]. Heavy metal-resistant strains also help plants to gain nutrients and phytohormones for optimal growth as reported by Zaidi et al. [51]. In our study, attributes associated with plant growth like root and shoot weight, plant height, and chlorophyll content were found to be significantly higher on the GAK2 treated plants with IS or IP. Our results are in line with previous findings by Madhaiyan et al. [52], where Burkholderia sp. strain CBMB40 and Methylobacterium oryzae strain CBMB20 mitigated Cd and $\mathrm{Ni}$ toxicity, and promoted growth in rice. In our previous study, it was found that E. ludwigii GAK2 could produce IAA and biologically active gibberellin(GA) [35]. Since, IAA and GA are widely reported to enhance plant growth, synthesis of GA and IAA by E. ludwigii GAK2 on the plant root rhizosphere could be one possible reason to confer tolerance and to stimulate growth. Moreover, our results are in agreement with Kang et al. [37], who showed that the silicate solubilizing bacteria Burkholderia eburnea CS4-2 promoted rice plant growth through silicate solubilization.

The presence of heavy metal usually causes stress to plants, inducing several metabolic changes as reported by Madhaiyan et al. [52]. During plant-microbe interaction, JA plays an important role in mitigating biotic and abiotic stresses. In the present study, GAK2 inoculation significantly lowered the JA content on IS and IP mediated soil. Similarly, JA related gene OsJAZ1 expression was lowered by IS + GAK2 and IP + GAK2 treatment. Shahzad et al. [41] reported that the gibberellin producing Bacillus amyloliquefaciens modulates the phytohormones, and lowered the JA content, in plants. Since, GAK2 has been reported for functional gibberellin production these might have played a possible role in JA regulation in plants. Moreover, similar trends were reported by Kang et al. [53], who found that endogenous JA content was lowered by the inoculation of gibberellin producing microbes.

Soil $\mathrm{pH}$ is considered as one of the most important factors affecting the availability of $\mathrm{Cd}$ [54]. It was reported that at $\mathrm{pH} 7.0$ the metal removal rate of $\mathrm{Cu}, \mathrm{Pb}, \mathrm{Zn}$, and $\mathrm{As}$ were high [55]. Numerous investigations have reported that there is an inverse relationship between $\mathrm{Cd}$ and soil $\mathrm{pH}$, as an increase in soil $\mathrm{pH}$ decreases the $\mathrm{Cd}$ concentration in plants. However, it has also been reported that although the availability of $\mathrm{Cd}$ in soil is affected by $\mathrm{pH}$, the increase in $\mathrm{pH}$ level of soil does not always reduce metal uptake by plants [54]. The sorption of $\mathrm{Cd}$ is affected by ionic strength, which varies widely among different soils [56]. Since silicate contributes to an increase in the soil $\mathrm{pH}$ level, this reduces the level of heavy metal uptake by the plants. However, accumulation depends on the genotype of a plant [57].

The abundance of silicate in the Earth's crust, and heavy 
metal pollution caused by phosphate fertilizer application, are both well-established facts. This study revealed that the Enterobacter ludwigii GAK2 could effectively solubilize the silicate and phosphate in soil, and thereby promote the growth of plants in $\mathrm{Cd}$ contaminated soil. In conclusion, this bacterial strain could be a suitable silicate and phosphate bio-fertilizer, that may reduce the requirement for the application of synthetic fertilizers, and decrease the $\mathrm{Cd}$ concentration in soil and crops. An extensive study is suggested on the spatial and temporal aspects of Enterobacter ludwigii GAK2, along with various forms of silicate, phosphate, and $\mathrm{Cd}$ in association with different crop plants.

\section{Acknowledgments}

This work was supported by the Basic Science Research Program through the National Research Foundation of Korea (NRF) funded by the Ministry of Education (2016R1D1A3B03931629). The author acknowledges the effort of Sanjeev Kumar Dhungana and Nikita Basnet for their kind support in performing the experiment. We are thankful for Kyungpook National University, School of Applied Biosciences for providing a well-equipped platform to conduct the experiment.

\section{Conflict of Interest}

The authors have no financial conflicts of interest to declare.

\section{References}

1. Khanna K, Jamwal VL, Gandhi SG, Ohri P, Bhardwaj R. 2019. Metal resistant PGPR lowered Cd uptake and expression of metal transporter genes with improved growth and photosynthetic pigments in Lycopersicon esculentum under metal toxicity. Sci. Rep. 9: 5855.

2. Rao K, Mohapatra M, Anand S, Venkateswarlu P. 2010. Review on cadmium removal from aqueous solutions. Int. J. Eng. Sci. Technol. 2.

3. Tóth G, Hermann T, Da Silva M, Montanarella L. 2016. Heavy metals in agricultural soils of the European Union with implications for food safety. Environ. Int. 88: 299-309.

4. Yang X, Long X, Ye H, He Z, Calvert D, Stoffella P. 2004. Cadmium tolerance and hyperaccumulation in a new $\mathrm{Zn}$ hyperaccumulating plant species (Sedum alfredii Hance). Plant Soil. 259: 181-189.

5. Sabiha J, Mehmood T, Chaudhry MM, Tufail M, Irfan N. 2009. Heavy metal pollution from phosphate rock used for the production of fertilizer in Pakistan. Microchem. J. 91: 94-99.
6. Su C. 2014. A review on heavy metal contamination in the soil worldwide: situation, impact and remediation techniques. Environmental Skeptics Critics. 3: 24-38.

7. Clemens S. 2006. Toxic metal accumulation, responses to exposure and mechanisms of tolerance in plants. Biochimie. 88: 1707-1719.

8. Aoshima K. 2012. [Itai-itai disease: cadmium-induced renal tubular osteomalacia]. Nihon Eiseigaku Zasshi. 67: 455-463.

9. Mulligan CN, Yong RN, Gibbs BF. 2001. An evaluation of technologies for the heavy metal remediation of dredged sediments. J. Hazard. Mater. 85: 145-163.

10. Gu H-H, Qiu H, Tian T, Zhan S-S, Chaney RL, Wang S-Z, et al. 2011. Mitigation effects of silicon rich amendments on heavy metal accumulation in rice (Oryza sativa L.) planted on multi-metal contaminated acidic soil. Chemosphere 83: 1234-1240.

11. Rajkumar M, Freitas H. 2008. Influence of metal resistantplant growth-promoting bacteria on the growth of Ricinus communis in soil contaminated with heavy metals. Chemosphere 71: 834-842.

12. Rogalla H, Römheld V. 2002. Role of leaf apoplast in siliconmediated manganese tolerance of Cucumis sativus L. Plant Cell Environ. 25: 549-555.

13. Liang Y, Yang C, Shi H. 2001. Effects of silicon on growth and mineral composition of barley grown under toxic levels of aluminum. J. Plant Nutr. 24: 229-243.

14. Neumann D, Zur Nieden U. 2001. Silicon and heavy metal tolerance of higher plants. Phytochemistry 56: 685-692.

15. Nowakowski W, Nowakowska J. 1997. Silicon and copper interaction in the growth of spring wheat seedlings. Biologia Plantarum 39: 463-466.

16. Chen H, Zheng C, Tu C, Shen Z. 2000. Chemical methods and phytoremediation of soil contaminated with heavy metals. Chemosphere 41: 229-234.

17. Wang L, Wang Y, Chen Q, Cao W, Li M, Zhang F. 2000. Silicon induced cadmium tolerance of rice seedlings. J. Plant Nutr. 23: 1397-1406.

18. Shi Q, Bao Z, Zhu Z, He Y, Qian Q, Yu J. 2005. Siliconmediated alleviation of Mn toxicity in Cucumis sativus in relation to activities of superoxide dismutase and ascorbate peroxidase. Phytochemistry 66: 1551-1559.

19. Shi G, Cai Q, Liu C, Wu L. 2010. Silicon alleviates cadmium toxicity in peanut plants in relation to cadmium distribution and stimulation of antioxidative enzymes. Plant Growth Regul. 61: 45-52.

20. Tubana BS, Babu T, Datnoff LE. 2016. A review of silicon in soils and plants and its role in US agriculture: history and future perspectives. Soil Sci. 181: 393-411.

21. Kumar A, Bahadur I, Maurya B, Raghuwanshi R, Meena V, Singh D, et al. 2015. Does a plant growth-promoting rhizobacteria enhance agricultural sustainability. J. Pure Appl. Microbiol. 9: 715-724. 
22. Nriagu JO, Moore P. 2012. Phosphate minerals, pp, 134-402. Ed. Springer Science \& Business Media.

23. Villalba G, Liu Y, Schroder H, Ayres RU. 2008. Global phosphorus flows in the industrial economy from a production perspective. J. Ind. Ecology. 12: 557-569.

24. Chowdhury RB, Moore GA, Weatherley AJ, Arora M. 2017. Key sustainability challenges for the global phosphorus resource, their implications for global food security, and options for mitigation. J. Clean. Prod. 140: 945-963.

25. Etesami H, Maheshwari DK. 2018. Use of plant growth promoting rhizobacteria (PGPRs) with multiple plant growth promoting traits in stress agriculture: Action mechanisms and future prospects. Ecotoxicol. Environ. Saf. 156: 225-246.

26. Islam F, Yasmeen $T$, Ali $Q$, Ali S, Arif MS, Hussain S, et al. 2014. Influence of Pseudomonas aeruginosa as PGPR on oxidative stress tolerance in wheat under $\mathrm{Zn}$ stress. Ecotoxicol. Environ. Saf. 104: 285-293.

27. Gupta P, Kumar V, Usmani Z, Rani R, Chandra A. 2018. Phosphate solubilization and chromium (VI) remediation potential of Klebsiella sp. strain CPSB4 isolated from the chromium contaminated agricultural soil. Chemosphere 192: 318-327.

28. Adesemoye AO, Kloepper JW. 2009. Plant-microbes interactions in enhanced fertilizer-use efficiency. Appl. Microbiol. Biotechnol. 85: 1-12.

29. Mukamuhirwa A, Persson Hovmalm H, Bolinsson H, Ortiz R, Nyamangyoku O, Johansson E. 2019. Concurrent drought and temperature stress in rice-a possible result of the predicted climate change: effects on yield attributes, eating characteristics, and health promoting compounds. Int. J. Environ. Res. Public Health 16: 1043.

30. Sun S, Zhou X, Li Z, Zhuang P. 2019. In vitro and in vivo testing to determine $\mathrm{Cd}$ bioaccessibility and bioavailability in contaminated rice in relation to mouse chow. Int. J. Environ. Res. Public Health 16: 871.

31. Farooq MA, Ali S, Hameed A, Ishaque W, Mahmood K, Iqbal Z. 2013. Alleviation of cadmium toxicity by silicon is related to elevated photosynthesis, antioxidant enzymes; suppressed cadmium uptake and oxidative stress in cotton. Ecotoxicol. Environ. Saf. 96: 242-249.

32. Rizvi A, Khan MS. 2017. Biotoxic impact of heavy metals on growth, oxidative stress and morphological changes in root structure of wheat (Triticum aestivum L.) and stress alleviation by Pseudomonas aeruginosa strain CPSB1. Chemosphere 185: 942-952.

33. Khan AR, Park G-S, Asaf S, Hong S-J, Jung BK, Shin J-H. 2017. Complete genome analysis of Serratia marcescens RSC-14: A plant growth-promoting bacterium that alleviates cadmium stress in host plants. PLoS One 12: e0171534.

34. Sharma RK, Archana G. 2016. Cadmium minimization in food crops by cadmium resistant plant growth promoting rhizobacteria. Appl. Soil Ecol. 107: 66-78.
35. Lee K-E, Adhikari A, Kang S-M, You Y-H, Joo G-J, Kim J-H, et al. 2019. Isolation and characterization of the high silicate and phosphate solubilizing novel strain enterobacter ludwigii GAK2 that promotes growth in rice plants. Agronomy 9: 144.

36. Kalra YP. 1995. Determination of $\mathrm{pH}$ of soils by different methods: collaborative study. J. AOAC Int. 78: 310-324.

37. Kang S-M, Waqas M, Shahzad R, You Y-H, Asaf S, Khan $\mathrm{MA}$, et al. 2017. Isolation and characterization of a novel silicate-solubilizing bacterial strain Burkholderia eburnea CS4-2 that promotes growth of japonica rice (Oryza sativa L. cv. Dongjin). Soil Sci. Plant Nutr. 63: 233-241.

38. Chan C-X, Teo S-S, Ho C-L, Othman RY, Phang S-M. 2004. Optimisation of RNA extraction from Gracilaria changii (Gracilariales, Rhodophyta). J. Appl. Phycology 16: 297-301.

39. Kim Y-H, Khan AL, Kim D-H, Lee S-Y, Kim K-M, Waqas M, et al. 2014. Silicon mitigates heavy metal stress by regulating P-type heavy metal ATPases, Oryza sativa low silicon genes, and endogenous phytohormones. BMC Plant Biol. 14: 13.

40. McCloud ES, Baldwin IT. 1997. Herbivory and caterpillar regurgitants amplify the wound-induced increases in jasmonic acid but not nicotine in Nicotiana sylvestris. Planta 203: $430-435$.

41. Shahzad R, Waqas M, Khan AL, Asaf S, Khan MA, Kang S-M, et al. 2016. Seed-borne endophytic Bacillus amyloliquefaciens RWL-1 produces gibberellins and regulates endogenous phytohormones of Oryza sativa. Plant Physiol. Biochem. 106: 236-243.

42. Ma JF, Yamaji N, Mitani N, Tamai K, Konishi S, Fujiwara T, et al. 2007. An efflux transporter of silicon in rice. Nature 448: 209-212.

43. Tirado R, Allsopp M. 2012. Phosphorus in agriculture: problems and solutions. Greenpeace Research Laboratories Technical Report (Review). 2.

44. Walpola BC, \& Yoon MH. 2012. Prospectus of phosphate solubilizing microorganisms and phosphorus availability in agricultural soils: A review. Afr. J. Microbiol. Res. 37: 66006605.

45. Naureen Z, Aqeel M, Hassan MN, Gilani SA, Bouqellah N, Mabood F, et al. 2015. Isolation and Screening of Silicate Bacteria from Various Habitats for Biological Control of Phytopathogenic Fungi. American J. Plant Sci. 6: 2850-2859.

46. Das P, Samantaray S, Rout G. 1997. Studies on cadmium toxicity in plants: a review. Environ. Pollut. 98: 29-36.

47. Metwally A, Safronova VI, Belimov AA, Dietz K-J. 2004. Genotypic variation of the response to cadmium toxicity in Pisum sativum L. J. Exp. Bot. 56: 167-178.

48. Rajkumar M, Sandhya S, Prasad MNV, Freitas H. 2012. Perspectives of plant-associated microbes in heavy metal phytoremediation. Biotechnol. Adv. 30: 1562-1574.

49. Lee KE. 2015. Silicon absorption promoting effect of rice by Enterobacter ludwigii GAK2. Master's Thesis. Kyungpook National University. 
50. Meharg A, Cairney JW. 1999. Co-evolution of mycorrhizal symbionts and their hosts to metal-contaminated environments. Adv. Ecol. Res. 30: 69-112.

51. Zaidi S, Usmani S, Singh BR, Musarrat J. 2006. Significance of Bacillus subtilis strain SJ-101 as a bioinoculant for concurrent plant growth promotion and nickel accumulation in Brassica juncea. Chemosphere 64: 991-997.

52. Madhaiyan M, Poonguzhali S, Sa T. 2007. Metal tolerating methylotrophic bacteria reduces nickel and cadmium toxicity and promotes plant growth of tomato (Lycopersicon esculentum L.). Chemosphere 69: 220-228.

53. Kang SM, Khan AL, Waqas M, You YH, Hamayun M, Joo GJ, et al. 2015. Gibberellin-producing Serratia nematodiphila PEJ1011 ameliorates low temperature stress in Capsicum annuum L. Eur.J. Soil Biol. 68: 85-93.
54. TRAN TA, Popova LP. 2013. Functions and toxicity of cadmium in plants: recent advances and future prospects. Turkish J. Botany 37: 1-13.

55. Govarthanan M, Mythili R, Selvankumar T, Kamala-Kannan S, Rajasekar A, Chang Y-C. 2016. Bioremediation of heavy metals using an endophytic bacterium Paenibacillus sp. RM isolated from the roots of Tridax procumbens. 3 Biotech. 6: 242.

56. Naidu R, Bolan N, Kookana RS, Tiller K. 1994. Ionicstrength and $\mathrm{pH}$ effects on the sorption of cadmium and the surface charge of soils. Eur. J. Soil Sci. 45: 419-429.

57. Li Z, Li L, Chen GPJ. 2005. Bioavailability of Cd in a soilrice system in China: soil type versus genotype effects. Plant Soil 271: 165-173. 